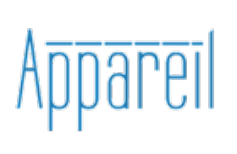

Appareil

11 | 2013

L'espace et l'architecture: état des lieux

\title{
François Dallegret: In Conversation with
} Alessandra Ponte

Alessandra Ponte

\section{OpenEdition}

1 Journals

\section{Electronic version}

URL: http://journals.openedition.org/appareil/1765

DOI: 10.4000/appareil. 1765

ISSN: 2101-0714

Publisher

MSH Paris Nord

\section{Electronic reference}

Alessandra Ponte, "François Dallegret: In Conversation with Alessandra Ponte », Appareil [Online], 11 | 2013, Online since 20 June 2013, connection on 30 July 2020. URL : http://journals.openedition.org/ appareil/1765; DOI : https://doi.org/10.4000/appareil.1765

This text was automatically generated on 30 July 2020 .

\section{(c) (i) (3)}

Appareil est mis à disposition selon les termes de la Licence Creative Commons Attribution - Pas d'Utilisation Commerciale - Pas de Modification 4.0 International. 


\title{
François Dallegret: In Conversation with Alessandra Ponte
}

\author{
Alessandra Ponte
}

\section{EDITOR'S NOTE}

L'ensemble des œuvres de François Dallegret est représentée et cataloguée sur son site web : http://arteria.ca/

1 François Dallegret profoundly dislikes interviews. Enchanting, enigmatic, mystifying, he is a master at evading questions, and has an amazing disregard for the spoken or written word (with one notable exception - he loves naming his projects). He also doesn't seem to believe in history, theory or criticism. But he reveres and worships images. 'I am an image maker', he told me repeatedly. Dallegret has portrayed himself to many different and equally baffled journalists in a variety of dissimilar ways. He seems to have a predilection for being described as a 'mad professor', a distillation of $\mathrm{D}^{\mathrm{r}}$ Mabuse and $\mathrm{D}^{\mathrm{r}}$ No. His long-time friend, the architect and critic Peter Blake, who first published Dallegret's extraordinary drawings very early in the architect's career, spoke of the fantastic world depicted by him as one of surprise and delight, but also added that he thought of him as one of his 'more outrageous cronies'. When I spoke to other friends and collaborators - like Joseph Baker, who worked with Dallegret on the amusement park at Expo 67, and with filmmaker Gerald Potterton, who started shooting, but never finished, a science-fiction western with Dallegret in 1966 - about the troubles I was having in prying out of François a reasonably truthful account of his career, both of them laughed uproariously at my naïveté.

2 Although he can be maddening, François always manages to remain perfectly charming and endearing. What follows is an account of an ongoing conversation with him that took place during a number of encounters between July and November 2008 and again between January and June 2011. Every time I went back to see him, after having painstakingly checked some of his stories against accounts published in magazines, 
books and memoirs, he was waiting for me with more astounding images and unexpected episodes of his colourful and eventful life. He would also be sweetly elusive about the misdirection and half-truths he had told me during my previous visit - for example, that he had never really had any interest in cinema or TV, only for me to discover that in 1966 he founded a short-lived company called The Wild Oats, 'to make films and a TV series for fun and profit', in collaboration with a young but already highly regarded Canadian filmmaker, Gordon Sheppard, and the illustrator, cartoonist and TV writer Tomi Ungerer.

During these encounters I discovered also the bottomless photographic archive of François. Negatives, prints and slides in every format that he digs up from the basement and attic of his house in Montreal. At each visit more appeared, re-arranged in different sequences, François's endless task. At first I was thinking of the obvious: photographs as traces of work in progress or finished products, snapshots as memory of encounters and events, and of course images used in photomontages. Eventually I began to realize that even the most casual snapshots were carefully choreographed. A lot were taken in studio by professional photographers often specialized in portraying art work. Two of them were Harry Shunk and János Kender, the photographers engaged in October 1960 by Yves Klein for his Saut dans le Vide (Leap into the Void). Like Klein, captured by Shunk and Kender while jumping into space from the top of a building, François performs in front of the camera. The photos factually become an essential component of the work, if not the "work" itself. François has photographs taken before drawing his fantastic machines to adjust their mechanisms to his body; he adopts various postures in front of the camera to test the different ways of sitting on one of his chairs; he carefully adjusts his naked form in order to inhabit the environmental bubble of 'A Home Is Not a House.' I finally realized that also the photo portraying François pretending to drive a Bugatti, or the image of François standing next to a gigantic reproduction of an "astrological" automobiles, and even the snapshot, dated 23 September 1968, of François in a plane piloted by Eliot Noyes on a flight from Connecticut to Martha's Vineyard, should be read according to the same code. The photographs are records of performances, the equivalent of works (of art). I learned not to ask François to expand on the "meaning" of the photos or investigate about the significance of the encounters. For example, interrogate about architect and designer Eliot Noyes, a pioneer in the field of comprehensive corporate design and famous for his work for IBM, Mobil Oil and Westinghouse, François responded that they were just celebrating the common birthday of their wives. The puzzling, often telegraphic, statements of François appear also to function as snapshots: images frozen in time of lost performances.

4 I am resisting the opportunity here to offer a synoptic biography of the man himself because his life and work always seems to deny anything quite so predictable.

5 Instead I prefer to transcribe part of my favourite text on François, presumably written by himself, for a 1970 double issue of Design Quarterly dedicated to 'conceptual architecture'. The editor, John S. Margolies, in a letter to each of the contributors (including Ant Farm, Archigram, Archizoom, Peter Eisenman, Haus-Rucker-Co, Craig Hodgetts, Les Levine, Onyx, Ed Ruscha and Superstudio), asked them to address the following concepts: 'the communication environment; the psychological environment; the entertainment environment'. The resulting pages dedicated to Dallegret, titled 'Have a Ball', began with a series of photographs of the belly of his enormously 
pregnant wife (she was close to giving birth to twins) and ended with the following text superimposed over a portrait of François holding a fusil à émotions, a weapon he had designed for his unfinished science-fiction western, 2020 west: 'Born Morocco 1937 French resident in Canada Bilingual Educated Paris BA Mathematics Ensba Architecture Experimental Designer Studios in Montreal \& New York Work with architects freelance in advertising and fashion Intense travelling and exhibition work in major galleries and museum in Europe United States and Canada Participation in the latest European Biennale and Triennale Mechanical drawings and editions Silkscreen and objects Construction of Sparks machines Walking cakes Jumping spheres Electrical and inflated garments Toys Modular playground structures Studies of multimedia package Mobile displays Collapsible structures and spaces for Multifunctional furniture.'

ALESSANDRA PONTE: François, you were born in 1937 in Morocco and your father was an engineer with the Trans-Sahara Railroad. After the war the family moved back to France, you did not adjust easily to the primary school system, displayed an early talent for watercolour, developed a taste for automobiles, and at a certain point began studies in architecture. Maybe we can begin from there, with the École des beaux-arts in Paris, where you studied between 1958 and 1963.

François Dallegret: I wasn't quite sure about becoming an architect at the time. I am still not sure. I was in love with automobiles and kept sketching new models of coupes. For some I used white pencils on black paper, quite sleek. I considered going to work for Raymond Loewy, the industrial designer, one of the streamline heroes. He designed these great automobiles like the bullet-nosed Studebakers of the Fifties, and the Avanti in the early Sixties. He opened an office in Paris in 1953, the Compagnie de l'esthétique industrielle, it was huge and they were designing logos for Coop, L'Oréal, Monoprix. When I was thinking about joining his office Loewy was also developing a fantastic Jaguar, but I discovered that later.

A.P. : Loewy, remarkable. In 1967 he was invited to work with NASA as habitability consultant and ended up collaborating to the design of the Skylab, which must have interested you too. Human life in space became one of your concerns. But at the time, I mean in the 50s, where you also fascinated with his lifestyle and design philosophy? The glamorous one depicted in the autobiographical Never Leave Well Enough Alone? It was published in the US in 1951 (the French translation came out in 1963 with the title of La laideur se vend mal). The quotation of Oscar Wilde at the beginning of the book, "One must be a work of art, or wear a work of art", may well have been your motto, at least judging from your photos at the time. You look like the young Yves Saint Laurent, a fashion icon.

F.D. : You are not the first to say that. Saint Laurent was just a year older than me and grew up in Algeria. However nothing came of it, I mean the idea of working for Loewy. It was just a possibility. I remember visiting the widow of Auguste Perret. I went with my mother in 1957, at the 51 rue Raymond (today seat of the Union internationale des architectes), and we met this tiny lady with her hair dressed à la Foujita.

A.P. : Why the widow of Perret? Because of Perret's plan for Havre, and the other huge postwar projects? And I suppose you refer to Tsuguharu Foujita, the Japanese painter friend of Modigliani, Picasso, Matisse and Man Ray? He became famous for his hairstyle, for his painting of cats and beautiful women, and also because of his flat with bathtub and running hot water in Montparnasse, a rare thing at the time. It made him very popular with the ladies. Your friend Banham would have approved of it too, good plumbing. Were you 
familiar just with the hairdo of Foujita or also interested in his Japanese ink techniques applied to Western paintings? There are some early drawings of yours that hint at experiments with ink and then of course you became a virtuoso of the Graphos drafting fountain pen. It was quite a demanding tool introduced by Pelikan in 1938, sold in sets that included a pen holder and up to sixty different nibs and three types of ink feeds. One set is visible on the drafting table in a photo of your studio in Paris in 1962. The text commenting your futuristic projects published in Architectural Forum in 1964 states "[the] drawings have the detailed precision of steel engravings, and seem to have been prepared with hypodermic needles filled with India ink." But this brings us back to your studies at the Beaux-Arts. What sort of drawings were you asked to produce during the first year there?

F.D. : We did highly precise rendering of the classical orders: Doric, Ionic and Corinthian.

A.P. : Seriously? Quite a conventional education, but was there any sign of the big explosion that was to come in 1968 ?

F.D. : No, not really. While I was there I never got the sense of an impending student revolution, although thinking about it now, every day there was always something going on, some kind of protest against various things happening in the world. At the time I was just too busy with design work to get into politics. The school was still structured around competitions and design charrettes and so we were always working through the night producing huge panels of drawings. It was a time when the École's ateliers were bursting with people - there must have been 300 students in each of them. I was on the quai Malaquais and having a great time. Except I was very shy when I first went to the school (I still am) and so in an attempt to overcome this and meet people I joined the school's band. The problem was that I couldn't read music and I'm tone deaf, so the only instrument I was allowed to play was the triangle. In performances all I had to do was ting the triangle. Despite these musical limitations I actually became director of the band. I remember one day we had to give a performance for Charles de Gaulle, then president of France. He was passing through the quai Malaquais with an official motorcade and we were all supposed to celebrate him. The place was full of police and secret service agents. We were dressed in ridiculous nineteenth-century Beaux-Arts costumes. The pomp and seriousness around this event made me go a bit crazy, and while De Gaulle was passing, as I led the musicians with my triangle, I dropped my trousers in the official Beaux-Arts style of saluting somebody. This was clearly not the thing to do in front of the president. The cops immediately jumped on me and dragged me off to the jail at St Germaindes-Prés. I was locked up all day while they went to my chambre de bonne on the boulevard St Germain to see if I had any bomb-making equipment or any evidence of some anarchist tendencies. They didn't find anything - only my pens and drawings and collection of clocks. And so they came back and after warning me to behave in the future they let me go. I have been a freeman ever since.

A.P. : But you once told me that you were never much of an instigator or especially engaged in politics.

F.D. : That's true. This was the exception. But for this one event I was always an outsider. I was really just engaged in what I was doing, except that looking back now I didn't really know what I was doing. Nevertheless I still carried on. After five years of school I did a project with Noël Lemaresquier who was the patron of my atelier at the École. [Noël Lemaresquier or Le Maresquier (1903-1982), Grand Prix de Rome, son of Charles Lemaresquier (1870-1972), also Grand Prix de Rome and teacher at the école des Beaux-Arts in Paris. Between 1943 and 1978 Noël Lemaresquier was in charge of 
the reconstruction of Saint-Nazaire. In 1954 he became Architecte en chef des bâtiments civils et palais nationaux. He taught initially at the école des Beaux-Arts of Toulouse, where his most distinguished pupil was Claude Parent, friend and collaborator of Paul Virilio and theorist of the oblique. From 1953 to 1974 Lemaresquier taught in Paris in the atelier previously directed by his father, from whom he also inherited his architectural firm in 1945. As expected, his teaching remained solidly anchored in the Beaux-Arts tradition. Among his students in Paris, one of the most famous was Roger Taillibert, known for his use of concrete 'sails' in large structures such as swimming pools and sports grounds, notably at the 1976 Olympic stadium in Montreal. Lemaresquier liked my proposal very much and asked if I would like to compete for the Prix de Rome. I said sure, why not, but three months later I packed my things and left for New York. All the same, the École at that time was really a great place to be, certainly in terms of the education it provided. You had to have a bit of talent to see you through - and lots of people dropped out, not quite fitting in with the school and its demands - but the main thing was just to get your mind going and try and do things that were a bit unusual. Being trained as an architect was a great way to learn because it was through the discipline of the subject that I really grew up, became a man. I mean it. As an architect you are boss of the field, of the chantier, and to be successful you really have to be on top of things. That's really what we learned at the École, or anyway that's what I learned.

A.P.: This is quite an extraordinary statement François, and surely one of your provocations. If anything you come across as rather undisciplined, a free spirit, a dreamer. You once described to me what you had to endure at the hands of older students at the École, as a shy newcomer who was the victim of nasty initiation rites. You even keep as a memento the photograph showing your sadistically shaved head. The 1968 rebellions at the school must surely have been against practices like this, and against teachers like Lemaresquier. In this sense, I am not surprised you abandoned your studies at the BeauxArts to go to America. But apart from the Beaux-Arts tradition, whose works were you all expected to follow at that time? Auguste Perret or was it Le Corbusier? Or were students enrolled in architecture aware of the Situationist activities, or the utopian visions of, let's say, Yona Friedman or Constant? Were you reading Michel Ragon in Architecture d'aujourd'hui and following the debate on megastructures and Urbanisme Spatial? Judging from the your 1962 "anticipatory" project for a pyramidal housing complex, 400 meter high, composed of standardized cells moulded in synthetic materials, you must have been rather well informed about the work of Ionel Schein, Alison and Peter Smithson, Pascal Haüsermann, Chanéac and others on the plastic house. It is clear that you must have known also the projects of Buckminster Fuller, Paolo Soleri, the Japanese Metabolists, and possibly the schemes of A. Chipkov and E. Chipkova for gigantic pyramidal settlements in Siberia. Your proposal may have been included in Justus Dahiden's Structures urbaines de demain (1972). In 1976, Reyner Banham discusses one of your projects for Montreal [the Palais Métro, 1967] in his book on megastructures. Is there a genealogy?

F.D. : No, not really. At the École there were all kinds of great people offered up to us but I was in a kind of vacuum. My only real reference was technology - at that time mostly automobile technology. I was drawing all the time. As a student I had to earn a living and so I was hired as a slave in various architects' offices. With this money I bought my first car - a Renault 4CV, and soon afterwards I got a 1937 Roadster Citroën, the first of many Citroëns, and then a type 57 Bugatti.

A.P. : The Bugatti 57 Carosserie Gangloff 1935. You had it for three years (1960-1963); the ownership is well documented. I love the set of photographs with you at the wheel, pretending to drive. The snapshots of your visit, with Bugattistes friends, to the Comtesse de Boigne, Ettore Bugatti's daughter, at the château d'Ermenonville are also great. The one 
with you inspecting the Bugatti La Royale Coupé Napoléon appears on the front page of the first issue of iris.time announcing your exhibition of fantastical automobiles. Experts say that the astrological automobiles you developed for Iris Clert are extreme versions of the most luxurious Bugattis produces in the 1930s, and Reyner Banham rightly calls your 1962 Super-Coupe de Long-Week-End, an automobile training a Unité d'Habitation Grand-Confort, "an historical capriccio from the First Machine Age". How did the show at Iris Clert come about?

F.D. : The whole thing happened by chance. In 1962 I met a woman called Iris Clert who ran her own gallery. She was crazy about my work and maybe about me too, and so she decided to organise an exhibition. The show opened in October 1962 and then voilà, it propelled me into certain artistic spheres.

A.P. : A few years before your show, Iris Clert organised a series of landmark exhibitions featuring the work of artists like Yves Klein, Jean Tinguely and Arman. The Iris Clert Gallery was located just around the corner from your school, at 3 rue des Beaux-Arts, and must surely have been very difficult for you to ignore. Looking at the dates of a few of her most famous exhibitions, always accompanied by spectacular parties taking place mainly in the street, I think you probably just missed Klein's 'Le Vide' and Tinguely's 'Mes Toiles: Concert pour sept peintures' from 1958 but you would have been in Paris during Tinguely's 1959 'Méta-matics' show, Takis' 'L'Homme dans l'espace' exhibition in 1960 or Arman's 'Le Plein'. The spaces that you inhabit, like the one portrayed in your spectacular panoramic photo of Reyner Banham visiting your atelier in Montreal, and your current house, all look a bit like 'Le Plein'. No one can accuse you of being a minimalist, of being in love with pure white empty spaces. Rather, you collect the most disparate things - toys, souvenirs, mechanical parts, models, magazines, exotic objects, mannequins, etc. Were these spaces of yours or the work that you did at the time influenced by your exposure to galleries or familiarity with that whole art scene?

F.D. : I met Tinguely in Paris when the gallery of Iris Clert was still on the rue des Beaux-Arts, and later in Montreal of course I saw his work for Expo 67, the Paradise realized with Niki de Saint-Phalle on the roof of the French pavilion, and Requiem for a Dead Leaf at the Swiss pavilion. As for Yves Klein, I did help him to find "living brushes" (girls) for his anthropometric drawings. We went looking at the Alliance Française on Boulevard Raspail. This was in 1959-1960. I discovered later what else he was doing, I mean the projects with Claude Parent for air-conditioned cities. In 1966, I met the photographers of the "The Leap into the Void", Harry Shunk and Janos Kender. They came to Montreal and visited my studio on rue Sainte Catherine. They photographed intensively my work over a period of two years. They were doing the same for all the artists working on the French pavilion for Expo 67: Tinguely, SaintPhalle, Bernard Quentin and Xenakis. But, I was never part of any scene. Although Paris at that time was a great city and a place very much full of 1960s happenings, they were not really happening my way. I knew something about the GRAV guys (Groupe de recherche d'Art Visuel) but beyond that I was aware of very little else going on in art and architecture. But then I was introduced to Iris, who responded immediately to the drawings of various automobiles and machines that I had been working on. Iris was great. She was Greek and a little bit nuts like me. She had a wonderful sense of humour and was always good at telling stories. She was also always surrounded by a coterie of artist friends and despite the fact that she never really had any money she still carried on, tapping up rich friends for donations and support. At the time she had moved the gallery to 28 rue du Faubourg Saint-Honoré. The 1962 show itself focused on a series of astrological automobiles. The inspiration came from encounters with a seer-astrologer, Madame Annekof. I went to the see her 
regularly with my mother in the late 50s. I proposed the idea to Iris. She was crazy about the whole subject, and even had her own private astrologer, Elzine, but she was not alone. In the early 60s in France there was a huge fashion for astrology and horoscopes. So tapping this craze I had the idea of producing a series of astrological automobiles -12 automobiles, each corresponding to a sign of the zodiac.

A.P. : What is your own sign?

F.D. : I am a Libra - apparently a good sign to have. That's what I think anyway.

A.P. : In the famous photograph from the time you are seen posing next to a full scale reproduction of the Super Leo. Iris Clert in her autobiography says that she wanted a "hyperrealist" ambiance: soundtrack of a race at Minneapolis and at the entrance visitors had to pay a symbolic Franc to go through a turnstile, like at the Salon de l'Auto. She even contacted the Minister of Transportation.

F.D. : The Super Leo was a super car, part of a series of 14-inch drawings I did for a sports car. I imagined it as made out of sheets of gold, with platinum coachwork and a mink-lined interior. For the 1962 exhibition I had the drawing enlarged and mounted on plywood. The whole thing ended up being seven metres long. The other cars were designed according to the characteristics of their corresponding star sign; so the Taurus was a huge, powerful vehicle without any brakes, the Libra had two steering wheels at opposite ends of the chassis and the Pisces was designed to sway to simulate the motion of waves.

A.P. : Apart from the automobiles you were also producing drawings of rockets and various types of machines. One of your rockets appears on the cover of the fifth issue of Iris. Time Unlimited (April 1963), the legendary little magazine created by Iris Clert a year before in connection with your automobile show. You also appear on the cover of that first issue of Iris.Time and according to Iris's memoirs, your friend and colleague at the Beaux-Arts, Paco Rabanne, wrote an enthusiastic description of your super-luxe models. Abandoning architecture, Paco in turn was launched into the world of fashion in 1966 with his own show at the Iris Clert Gallery. You seem to have shared with him a fascination for futuristic clothes, like the ones you designed for a science-fiction western in 1966, and you seem really obsessed with hats; you designed the most outrageous headgear and managed to convince quite a number of your friends to wear these 'objects'. Someone also once told me that you created a memorable birthday dress with twinkling lights for Phyllis Lambert. But I'm anticipating too many things. Let's stay with your machines for now.

F.D. : Yes, during the early 60s, all my work took the form of big drawings - of machines, rockets and other prototypical computer-controlled devices -which took me up to three or four months to complete. They were all drawn with a Graphos pen and were made up of thousands of really fine straight China ink lines. Initially I worked on vellum but later switched to acetate because you could just scratch off the ink when you made a mistake and then redo the line. I still have all the drawings. Acetate is not especially fragile and is easy to archive.

A.P. : From the drawings one gets the impression that you had been reading a lot about cybernetics, which in France especially at that time was developing a real momentum. Was this the case?

No, no, I have never been a big reader.

A.P. : Yes, so you say. You emphatically state "Ne lit plus" (Stopped reading) in Une partie de la vie de François Dallegret, the undated typescript you recovered from your papers. And a lot of your lifelong friends have confirmed this to me - apparently you just read newspapers and absorb ideas on the go. They also talk about your frenetic travelling and your obsession with the telephone. But, then, if not books what about the movies? Did you 
get your ideas from seeing 60s science-fiction films in cinemas in Paris, for example Marker's La Jetée or Godard's Alphaville? I read an old interview with you from 1966 in which you said that you wanted to get into the movies.

F.D. : Did I say that? Incredible. Or at least I was not thinking about the movies when I was in Paris - all I did at the time was to go to a little movie theatre on rue de Ranelagh quite often, which was interesting not just because of the films they showed but because it had a huge glass television-like screen that presented moving images through rear rather than front projection. It was these kinds of everyday encounters, rather than specific books or films, that really sustained my interest in technology. Much of the resulting material was published by the Iris Clert Gallery but my rockets were also reproduced in Architectural Forum. Of the other drawings I made at the time I also did a cooking machine that you sit on and control all aspects of the cooking process, and a writing machine to create your own literature, which comprised a seat, a screen and a computerised controller - or rather what I called a computerised controller.

A.P. : A machine à réaction poétique?

F.D. : Yes, exactly. That's a really good name for it. Where did that come from?

A.P. : I guess it was a definition that circulated at the time in different artistic milieus; Le Corbusier for example in the 60s was talking of objets à réaction poétique to explain his enduring interest in organic forms - bones, driftwood, shells, etc.

F.D. : Oh, I didn't know that. That's nice. I should take note of that. Another machine from 1965 was developed for a public relations firm. They reproduced my drawing and sent it out as a Christmas card to their friends and clients. It was a machine that created PR. It was not exhibited at Iris Clert but was the result of a private commission.

A.P. : All of these machines remind me again of Le Corbusier's famous expression that 'a house is a machine for living in'. Architects have mainly taken this literally, but I always wondered if one can understand it instead as a sort of surrealist machine à réaction poétique - the house as a poetic machine, an objet à réaction poétique. And this brings to mind another extraordinary lady who took a great interest in you in Paris. Again my source for this is the memoirs of Iris Clert - she writes that Marie-Laure vicomtesse de Noailles was rather smitten with you and that you were invited repeatedly to déjeuners at her hotel particulier at 11 place des États-Unis (today the musée Baccarat). Marie-Laure, herself a painter and sometime exhibitor at the Iris Clert Gallery, had been a friend since childhood of Jean Cocteau. She was patron to Luis Buñuel (she commissioned his surrealist film, L'Âge d'or) and also Man Ray, who made his own 1928 film, Les Mystères du Château de Dé, in her famous villa. The villa itself, designed by Robert Mallet-Stevens, may be considered a surrealist machine for living, equipped as it was with multiple apparatus and devices including clocks in every room and a revolving sculpture pedestal at its entrance. Did she suggest the visit to Salvador Dali at Cadaqués?

F.D. : No she didn't. I went with my mother to see him in Spain in 1960, before meeting Marie-Laure. I kept all the photos including snapshots of Salvador and Gala during a boat excursion. He loved my automobiles and called them "fantasticotomobiliassimos". We met again in New York at the San Regis Hotel in Chelsea in 1964. He was surrounded by nymphs, gorgeous women all dressed in white. One was Mia Farrow. Four years later he saw me coming out of the elevator at the San Regis. I was with my wife Judith. She remembers that he kept calling me "My son! My son!" and then asked if I had something for him. He knew I always carried in 
my pockets buttons with images of my automobiles, baby dolls and stamps for printing my God \& Co signature on every possible surface.

A.P. : Of course your God moment, we will come back to that. Did you ever show to Salvador Dali your collection of doll's eyes? You mention it in your autobiographical fragment specifying that when needed you pulled the eyes out by yourself. I am sure Dali would have appreciated. All I can say is that it is reasonable to suspect, François, that in the early 60s in Paris you were producing a new generation of surreal machines inspired by the space race and cybernetics even though, as you have said, the computer, especially in France in the 1960s, was still a dream for the majority.

F.D. : Well, I was completely in the woods, unaware of anything going on around me.

A.P. : But what about the artists of the GRAV? You said before that you were following their activities. I did some checking. They exhibited in Europe within the framework of the Nouvelle Tendance and were active in Paris between 1960 and 1968. They produced their most important work, cooperative events called Labyrinths, after you left Paris. However, in 1960 they were holding public debates in their studio including one with Victor Vasarely and Nicolas Schöffer, that had already produced some of his cybernetic- spatiodynamic, constructions (CYSP). His first cybernetic tower was presented at the Building and Public Work Exhibition in Paris in 1955. I wonder if you François were present at the debates. The GRAV manifesto Enough of Mystification (Assez de mystifications!), was published in 1961 for the Paris Biennale. Member of the group were Horacio García Rossi, Francisco Sobrino, François Morellet, Julio Le Parc, Joël Stein and Yvaral (Jean-Pierre Vasarely, son of Victor Vasarely), while Nicolas Schöffer seemed to have remained loosely related to them. I am sort of surprised you were interested because they were politically engaged, and against the "romantic" idea of the artist as solitary genius and tried to merge their identities in collective activities. You were never much for collaborative efforts, nor politics. What is more, the scientific ambition and technological proclivity of GRAV were almost antithetical to the researches of Klein and Tinguely. Klein did seem adverse to science and technology, after all he proposed to hide the technological apparatus for his air-conditioned cities underground, and his Chelsea Hotel Manifesto (1961) he wrote: "Neither missiles nor rockets nor sputniks will render man the 'conquistador' of space [...] He will be able to conquer space - truly his greatest desire - only after having realized the impregnation of space by his own sensibility." As for Tinguely his walking, talking, drawing, fighting, copulating, hilarious, malfunctioning, incompetent, sad, self-destructive meta-machines deliver, to say the least, an ambiguous message about technology, art and life. Did you feel more affinity for the position of GRAV?

F.D. : Possibly, my machines did not self-destruct, I was in love with them.

A.P. : Yes you did, and eventually you produced The Machine, a real cybernetic apparatus, exhibited in New York in 1966. A photograph of the installation was published by Jack Burnham in Beyond Modern Sculpture: The Effects of Science and Technology on the Sculpture of This Century (1968). It is quite remarkable to see your work reviewed by one of the major American art critics of the 60s. Jack Burnham is considered as the major force behind the materialization of system art. In Beyond Modern Sculpture, the source of most of my information about GRAV, Burnham firmly places you in the chapter devoted to cybernetic art (that he separates from kinetic art). Your work appears next to Nicolas Schöffer that in 1965 presented at the Jewish Museum in New York models and drawings of a future Cybernetic City. So The Machine represents your only real foray into cybernetics?

F.D. : La Machine, was made a year before Expo 67, with the help of the Canadian manufacturing firm Raymond from Lachine. They were working on the extrusions for the French pavilion designed by Jean Faugeron, a structure that is actually still standing today, forming part of the Montreal Casino. The extrusions were piled up at Raymond's and they gave me the idea of producing a machine made out of a similar 
set of parts, or specifically two horizontal $10 \mathrm{~m}$-long anodised aluminium sections, the upper one incorporating fluorescent tubes and the lower one 144 photo cells. The whole thing was connected to a sound system. The idea was that just by placing your hand in the central void space of the structure, without even touching anything, you would create your own sound. Multiple hands, with their attached bodies and heads obscured by the upper part of the machine, could create other sounds simultaneously, and so it was as much a social structure as a sonic one.

A.P. : A cybernetic machine without doubt. But what about the space artist equipped with Cosmic - Opera Suit you present in the same year in Art in America? He had quite a progeny; you produced a number of versions of figures that looks like cybernetic Vitruvian men. The short text that accompanies the drawings in Art in America, points in the direction of Klein's immaterial art of sensations and affects. Electric emanations are described as the medium employed by the artist of the future to create environments. You are quoted saying: "...in this future everyone will understand the artist's intention. His intention will be to create all sorts of natural and supernatural feelings we don't know about yet. It will kill Descartes, this thing. And Braque." Tell me more about your collaboration with Art in America, who published a lot of your drawings and work?

F.D. : I was introduced to the editor, Jean Lipman, by Peter Blake, who at the time was an editorial consultant to the journal. Jean then became quite enthusiastic about me. I did a series of articles for them between 1965 and 1967. Art in America was crazy about what I was doing and so gave me carte blanche to submit anything I liked. The drawings and montages and articles I produced were all part of this. The text and layout of the images - particularly the negative reversal of my line drawings - was done in collaboration with the editors and designers at the magazine. I needed help with the text because I am not really a writer. I used to write crazy little notes and comments and lists of ideas all the time but I couldn't make enough sense of them to get them published. They used to pile up as notes all over my chambre de bonne in Paris.

A.P. : But by this stage, of course, you had left Paris and were living first in New York and then in Montreal. Why did you decide to leave Paris and move to the US?

F.D. : America was always a dream for me at that time, a land to conquer. Despite the exhibitions I had at Iris Clert I was feeling restless in Paris and didn't like the climate and the people. Paris and ultimately France just seemed like places to leave. And so I travelled with a friend on the transatlantic liner the France and ended up in New York. It was Peter Blake who convinced me to choose New York. He was then editor of Architectural Forum. Peter had published some of my drawings and in the process we developed a close friendship. Through him I also met other people in the city, for example Paul Bianchini, the famous pop art dealer who had a gallery, then Dick Waddell who also ran a gallery.

A.P. : How long did you stay in New York City? And who was the friend you travelled with? I think you once told me it was Bernard Quentin, an artist who himself was moving between painting, calligraphy, sculpture, architecture and land art. If I remember correctly, at some point you also travelled across America with him.

F.D. : I remained in New York for about a year (September 1963 to August 1964). I was staying at the Chelsea Hotel on $23^{\text {rd }}$ Street. And yes I came over with Bernard Quentin. We went on a great trip across America. In January 1964, we flew to New Orleans and from there, we drove a small Fiat to Los Angeles, seeing the desert on the way. He was one of my Bugattistes buddies and of course part of the circle of Iris Clert. He was an older friend. At the time he was just back from Italy where he had 
conducted experimental work on writing at the Olivetti centre for electronic research in Milan. Bernard was employing an oscilloscope to give graphic expression to the rhythms of his manual writing. This scope translated onto paper an imprint of Bernard's body - the respiration, the pulsing of the heart, all of the body's movement. But he was unhappy with the results and decided that only a pneumatic sculpture with electronically programmed respiration could translate the rhythms of life, the quivering of the inner being. And so with the help of the Pirelli factory in Milan he built his first Cybule. Bernard was coming to New York to propose a Cybule III at the World's Fair. It didn't have a great impact, but Salvador Dali really liked it. Dali offered him a lot of encouragement and proclaimed him a pioneer of cybernetic and electronic art. In 1964 the director of the Guggenheim, Lawrence Alloway, asked Bernard to organise a happening with an inflatable environment. Nothing came of this but Bernard tried again later in Montreal at Expo 67, with Jean Faugeron at the French pavilion. He did a complete inflatable environment on the terrace. Bernard proposed also an inflatable pavilion for Osaka in 1970. That one was not realized, but four years later, for the bi-centenary of the USA, Bernard managed to build in Chicago the world's biggest inflatable sculpture, a 120 meters long and 26 meters high "Venus".

A.P. : You both arrived when pop art was exploding in New York. Did you ever meet Andy Warhol and other pop artists there?

F.D. : Yes, of course. I wouldn't say that Andy Warhol and I were close friends, but we often used to run into each other. I remember once sitting at the Max Kansas City, a bar in downtown Manhattan with Andy and my future wife, Judith, in 1969 I think, when the largest cockroach I ever saw crawled along the top of the banquette. New York was a city of cockroaches.

A.P. : It still is. And I don't know whether it had anything to do with the cockroaches, but later, of course, you visited Montreal for a couple of weeks and then decided to stay, though you kept commuting back and forth to New York. Some publications in the late 60s describe you as an artist with offices in Montreal and New York, and your friends, including the filmmaker Gerry Potterton, recall memorable trips to New York in one of your white Jaguars (apparently you had at least three of them) that you used to park with great nonchalance in the most disreputable parts of New York City. Gerry told me that you used to drop in not just at Andy Warhol's place, but also visited Roy Lichtenstein, and that in general you loved to roam around the Village and kept encountering the most amazing people, like Bernardo Bertolucci asleep on a floor after a party in an empty loft.

F.D. : Yes, that's right. Originally I had no plans to move to Canada but while I was in New York I was contacted by a designer I had collaborated with in the past, who was then working on the preparations for Expo 67 in Montreal. The Canadians were looking around for talent, for artists and designers who could contribute to the Expo. In late 1965 I was approached and asked to be part of this team, and I visited the city initially just to get a sense of the place. I remember staying in a little house on La Montagne. I had met Bill Sofin who was a pharmacist in Montreal when I brought him a present from a friend in New York. We soon got talking and he asked me about my plans. I just said that I was looking around. He mentioned that he was hoping to commission a drugstore and asked if I would consider designing it. This is how I got the contract for the drugstore at 2130 Mountain Street. Later I lived in an apartment above the store while we were working on the construction. Bill was an interesting guy, and from the outset was very keen that we should create a place where people could not only buy pharmaceutical products but could also meet and talk to friends. 
The result was Le Drug, and in addition to designing the conversion for the store we also designed Le Drug's logo as well as posters, badges, bags and match books. The building itself was a typical Montreal house - with a narrow front and back and an elongated middle. I put a restaurant in the basement and had the drugstore above it at street level. At the back of the pharmacy I also designed a little fashion boutique and a small gallery - Galerie Labo - which I ran myself. It was at Labo that I showed all my work and that of other friends.

A.P. : Was it largely pop art that you were showing at Galerie Labo?

F.D. : I was interested in what was happening at the time and so we exhibited all kinds of things, not just pop. For example I showed the work of Paul Thek, who was producing some beautiful pyramidical glass structures to be used for meat packing.

A.P. : Are you talking about the 'technological reliquaries' that Paul Thek was developing between 1965 and 1967, including the Meat Piece with Warhol Brillo Box of 1965? I wouldn't call them beautiful - they were disquieting slabs of meat realistically reproduced in wax, body parts with vestiges of armour still attached to them. They were conceived as a protest against pop art's embrace of mass-production and minimalism's enthusiastic celebration of technology, or at least this is how they were perceived at the time. Thek was considered a successor of dada and surrealism and listed as a great 1960s art eccentric, alongside Bruce Conner and Edward Kienholz. His best known large-scale technological reliquary, the environment titled Death of the Hippie, a mastaba-like monument painted in garish pink and containing the wax effigy of the artist, had probably more resonance in Europe, especially in Germany, where Thek became close to Joseph Beuys and arte povera, than in North America. He is still quite popular in Germany - the ZKM (Zentrum fur Kunst und Medientechnologie, Karlsruhe) just organised a huge retrospective of Thek's work.

F.D. : Yes, it was all quite experimental stuff, but Labo only lasted for two years.

A.P. : The construction shots of the restaurant make it look like something out of Kiesler's endless house, but when completed it is all shiny, with a plastic like appearance, a sort of glossy womb with plenty of smoothly finished recesses. One image is especially revealing, the one with you lying in a highly polished organic alcove. In fact, in a beautiful 1966 issue of Aujourd'hui: Art et Architecture, Le Drug features just a few pages away from a large profile of Friedrich Kiesler. More precisely Le Drug was grouped with a series of experimental works characterised by a search for the renewal of architectural form in away that approached what the editors called the 'freedom of sculpture'. You are listed together with André Bloc, Hans Hollein, Walter Pichler, Christian Hunziker, Walter Förderer, Piotr Kowalski, Charles Deaton, Jacques Bertrand, Herbert Goldman, Jacques Couelle and John Johansen. Do you think your own research had affinities with the work of these artists and architects?

F.D. : I'm not sure of its artistic allusions, but in terms of the design of the restaurant at Le Drug everything was made of regular stuff - standard tables and chairs - but I wrapped this furniture with wire mesh and then sprayed it with cement. It was then polished and epoxyed. The same process was used on the walls. Because the space was a basement with a low ceiling we also had to have a ventilation system, a network of pipes that hovered above each table and also incorporated a light. People sitting at the tables could control the light and the air flow, just like passengers in an airplane. Despite these technological allusions everything really just referenced its own materials - and these were all simple, readily available things because there wasn't much of a budget. Maybe because of this the Le Drug restaurant and bar ended up being very successful. For upstairs, in the pharmacy, I adopted the opposite approach - everything was square and orthogonal. Shapes were still dropped from the ceiling but they were always square and finished in either black or white. 
A.P. : But you did know Kiesler, he even wrote to you, and you did admit the basement space of Le Drug was conceived as womb-like, a shape you explored again in the almost contemporary drawings for "A Home Is Not a House". Maybe we can come back later to the womb figure. Let's go back to Montreal in the 60s. For source material and information on Le Drug and many of your other projects I have been using a secret weapon - a great book called Québec Underground 1962-1972. Published in 1973 in three volumes it depicts the whole of the art and design culture of Montreal, and reading it I have really started to appreciate the underground art scene in the city at that time. In the third volume there is a huge section dedicated to your work, which is presented alongside that of other notable Canadian artists. The book groups you all under the heading, 'The Lone Rangers', and goes on to state that to really appreciate this definition you have to understand Lucky Luke as he sings, 'I am a poor lonesome cowboy'. The other lonesome cowboys were Jean-Paul Mousseau, Germain Perron and Maurice Demers. Mousseau was older and a really big name at the time. A member of the Automatistes, in 1948 he had signed the legendary manifesto Refus Global that rejected all the values and norms of Quebequois society and marked the birth of modern French Canada. He had produced important abstract art work for the subway system in Montreal and realised his famous sculpture lumineuses, including the moving mural or living fresco for the Hall of Hydro-Québec (1962). Germain Perron, celebrated as the precocious genius (born in 1948 in Montreal, he had his first solo exhibition in Paris at the Galerie Fachetti in 1965) had completely transformed stage design in Canada by the end of the 60s. In 1967 he had been in charge of the design of Citérama (24 scenes on two concentric disks rotating at different speeds, and six screens offering infinite combinations of images) and the stage design and costumes for La Cité des Solitudes, as part of the L'homme dans la Cité pavilion at Expo 67. Maurice Demers came to the fore in 1968 with his extremely fortunate Futuribilia, a science-fiction environment, and the following year built Les Mondes Parallèles at the Insolite pavilion. By the beginning of the 70 s he was systematically practising and theorising a total environment theatre. You guys actually had interests in common, especially you and Demers, with science-fiction.

F.D.: Yes but that name, the Lone Rangers, was really apposite. Although they grouped us together we were all alone, never really working collaboratively or as part of a collective or movement.

A.P. : It is interesting that you say that, because in the book there is an interview with Mousseau from the mid-60s in which he says, 'That's it, I'm leaving Montreal, there is no space here for experimentation, I have to go to New York', etc., etc. And yet this was exactly when you were arriving in Montreal and finding all these opportunities to express yourself.

F.D. : When I arrived, Montreal was such a great place to be. It had a thriving art culture, especially between 1966 and 1975 (after that things kind of collapsed). Mousseau was born in Montreal and lived here all his life, so maybe he just needed to get out. For me, coming to Montreal as an outsider, I found the atmosphere stimulating.

A.P. : The whole 67 Expo experience must have been interesting too. Weren't you in charge of the amusement park?

F. D. : Yes, that's right. I'd had the idea of taking over the La Ronde area on the Expo site and creating another kind of space. I formed a group of four people and we were supposed to design something collectively but we got together too late, even if we did manage to present a rather interesting proposal. The main piece was an electronically controlled curtain of water at the entrance, and I invented two machines, the Mimisonic and the Ballomatic. The first was an electronic device which enabled people to play and dance to their own music, and the second consisted of large spheres mounted on pivot spokes, activated by a small internal motor that produced a waving motion. Ultimately we just did our own individual installations - I 
did the pin-wheels, or wind flowers; Norman Slater, an architect, did the lights; Leonard Levitan, a designer from New York, did banners and Joe Baker did the layout and the colourful fluorescent kiosks, inspired by his children's construction toys.

A.P. : Rather like these Expo installations, Mousseau's own work was also very much into the idea of creating total environments. In Montreal after the Expo these environments typically manifested themselves as discotheques - places like Le Crash and the MousseSpathèque, legendary discos designed by Mousseau. In the 1970s the city was famous for its disco scene. Did you ever go to these places?

F.D. : I think I went to Le Crash a few times but I was more concerned with my own music venue, The New Penelope Coffee House, which I set up in 1965 - not so much a disco as a place where US groups came and performed, for example, people like Frank Zappa. I designed the whole space out of scaffold tubes. I was really into scaffolding at the time, the whole idea of temporariness and ephemerality was so big then. Like Mousseau, though, I was also designing other all-encompassing spaces, the main one of which was the Palais Métro project from 1968, for a site now filled by Montreal's Grande Bibliothèque. Me and Joe Baker were planning on taking over the existing Palais du Commerce, abandoned after the creation of the new, bunker-like Place Bonaventure and its centre de congrès. The Palais was a huge hangar where people could go ice-skating as well as a venue for large conferences and civic gatherings. I produced a scheme linking the hangar to the metro below - hence Palais Métro - and to a whole new village of shops and bars, a sort of Fun Palace à la Cedric Price. We organised a big campaign to encourage investors, putting together a series of six suitcases containing drawings and photomontages and a tape recorder with samples of the sound-environment envisioned for the space, and a very convincing and aggressive speech selling the scheme. We were trying to interest individual boutique owners in the project but because this was so soon after the 67 Expo everyone was tired of the grand municipal project, and besides they didn't really have the funding. The following year I revisited the theme and published in Esquire in May 1969 a Fun House. Because both of these projects ultimately didn't happen, I reintroduced many of the proposals again in 1972 in a project I did with Joe Baker for Hallmark Cards in Kansas City called West Village. It was perhaps this project, right in the heart of the US Midwest, that helped influence the 'Lone Rangers' tag.

A.P. : Did you wear cowboy boots at the time?

F.D. : Yes, of course. I still have one somewhere.

A.P. : Only one?

F.D. : The other one can't be too far away. They were a great pair of boots, given to me by Jean-Pierre Raynaud, a French artist I'd met at the Chelsea Hotel in New York. Probably you have seen is trade mark flower pots filled with concrete. At the time I loved boots. They were all I would wear. I was really très chic at the time.

A.P. : Yes, you really were Le Sage. You weren't a hippy with long hair and sandals.

F.D. : No, not at all. I was quite clean cut.

A.P. : But at the time, and ever since, maybe because of your sharp suits everyone had trouble pinning you down - you defied definitions and escaped categorisation.

That's the way things have always been with me. 
A.P. : Let's go back to Art in America. As you mentioned earlier you supplied your own drawings and then the editors at the magazine introduced some text. It strikes me that in nearly all of your projects there is always this secondary introduction of narrative.

F.D. : I think that's true. And I have always regarded this text as integral to the project and the images. In 2007,when I had a show at the musée d'Art Moderne in Luxemburg, I insisted that the museum display the corresponding pages from Art in America alongside my original drawings just to show that one could only be understood through the other. I had a really hard time convincing the curators of this. They gave in, eventually, but only a couple of weeks before the show closed.

A.P. : The one exception to this pattern of counter narrative was the 1965 'A Home Is Not a House' publication you did with Reyner Banham for Art in America, where the text was created at the same time as the drawings.

F.D. : Yes, that's right. I had been introduced to Banham in New York by Peter Blake, before the Art in America articles. We immediately got along. I went back to Montreal and worked on the drawings for the project and we then had a series of correspondences getting everything right. The final drawings were not published in Art in America because they would not have reproduced so well at the time - they were such fine line drawings - now of course reproduction techniques are much improved, you can do almost anything. But I still have the originals.

A.P. : You recently said that you "just" expressed Banham's idea. I think this is one more mystification, like the amusing anecdote about Banham refusing to be portrayed in the nude. Allegedly you generously provided images of your naked body for the photomontages representing the inhabitants of the environmental bubble. Banham's bashful reaction would have therefore deprived architectural audience of the image of a liberated critic enjoying the technological Eden heralded in his writing. I am sure you helped to propagate this legend. However the timing, you produced the images in Montreal while Banham was otherwise engaged in the States, and what survive of the preparatory work, two sets of sketches on yellow tracing paper and a series of black and white photographs of yourself in a state of (progressive) undress, appear to contradict the narrative. Did Banham send you at least the images of his profile and photos with sunglasses and cigar used in the photomontage?

F.D. : As I remember it now he must have given me some of his photos.

A.P. : Seen in the context of your way of functioning anyway Banham's absence or refusal to drop his pants are not so relevant. Images of yourself, dressed or undressed, had been for quite a while essential in the making of your machines. Moreover, Banham at a certain point in the text rhetorically asks: 'But... surely this is not a home, you can't bring up a family in a polythene bag?' After mentioning the 'countless Americans who are successfully raising children in trailers', he goes on and tries to demonstrate that to do such a thing is a pretty good idea. For Banham, apparently, the environmental bubble, an extrapolation of tendencies already present in American domestic architecture and way of life did not require the identification of a completely novel type of inhabitant. I think, on the contrary, that the multiple representations of your body in different attitudes and the fictional, "mediated", conversation with the disembodied Banham, precisely articulate the figure of the bubble's new dweller. I suspect in this resides also the endless fascination for the image of the environmental bubble, which has been published and commented upon innumerable times. In a topical essay, Christopher High, even if doesn't mention you, gets really close to the point I am trying to make, when he writes: "...the bubble emphasised a hyperindividualism. For Banham, this provided for an implicitly molecular body politic more suited to post-war societies' social transformations and 'liberated' practices of the self. 
Thus, the pneumatic bubble was not a primitive hut but an appliance for this new subject in a cybernetic garden of Eden - the anti-Oikos for the anti-Oedipus."

F.D. : I like that, where did you say he published it? Anyway I received recently a text titled 'Ecology without the Oikos: Banham, Dallegret and the Morphological Context of Environmental Architecture', in which the author, Amy Kulper, proposes a different interpretation. I am interested in her analysis too.

A.P. : Yes I know. So let me suggest one more. I think that the environmental bubble, that houses the multiple replicas of the body of its dweller, is an uncanny illustration of the 'dyadic monadology' theorized by German philosopher Peter Sloterdijk in his trilogy on spheres. Sloterdijk, borrowing from Leibnitz and Deleuze, consider the monad as the basic unit of comprehension and inhabitation of the modern world, and affirms that today we live in connected-isolation in an 'architecture of foam'. For Sloterdijk, after the Enlightenment and the collapse of classical metaphysics, the (spherical) image of the whole world as house has been superseded by a multichambered system composed of comparatively stabilized personal worlds. Modern architecture's invention of the unite d' habitation, or inhabitable cell, correspond to such metaphysical turn. What is more, with the unite d' habitation and the idea of the house as machine à habiter, began the process of explication, radicalized in the experiments of the 60s, that transformed the traditional dwelling in a totally environmentally controlled personal pod modelled on the space capsule. By explication Sloterdijk means the bringing to the foreground of what before constituted the background, i.e. the "life support system", or what Banham in the famous introductory paragraph to 'A Home Is Not a House' describes as the "complex of piping, flues, ducts, wires, lights, inlets, outlets, ovens, sinks, refuse disposers, hi-fi reverberators, antennae, conduits..." Sloterdijk speaks also of the construction of technological shells for life that functions as uterus repetitions of outdoor milieus. Here the idea of the dyadic monadology becomes clear. The bubble dweller, like the inhabitant of uterus, is auto-gamus and capable of self-supplementing him/herself. Integrated in a dyad with a real or imaginary Other, the bubble resident can simulate an entire social structure. This seems to correspond to what you represented François: the multi-polar bubble dweller engaged in a fictional conversation with a distant Other.

F.D. : That's nice.

A.P. : I thought you were going to like it. Did you and Banham stay in touch?

F.D.: Yes, he actually came to visit in 1967 and stayed at my place on SainteCatherine West. It was in this two-level studio apartment that I took a series of photographs of Banham, sitting by my fake fireplace, looking over some of my things. I am no photographer but the pictures came out really well. I have also kept all the letters he sent in which he asks if he could stay with me and talks about his interest in seeing the Expo. In this correspondence he always began each letter, 'Dear God', because at the time I was God, you know.

A.P. : Which was really something.

F.D. : It certainly was. The whole God thing stemmed from the credit cards that a number of Canadian banks had issued to me using the name God and Co. You would never get away with this today but back then it was possible. I just applied for the accounts and the cards under this name and voilà, they sent them through to me. God and Co was actually an acronym for 'Go Dallegret'.

A.P. : This is also how you sign your section in Jim Burns' book Arthropods from 1972. Some time after these drawings you then changed tack and started to produce real machines

F.D. : Yes, we already spoke about the first of these, La Machine. After being exhibited in New York it moved around the States to different venues, coming back to Montreal 
three years later. It has been sitting in a field I own ever since. But recently the auction house Phillips contacted me about selling a number of my pieces, including La Machine, KiiK and the Lit Croix, and so I have had to pull it back out of the field and work on it in a nearby barn. The problem is that to sell it I first have to spend $\$ 25,000$ on reinstalling all the electronics and making sure the thing works. KiiK was much less complicated. It was just a little device to fiddle with - a functional product, as I described it at the time, designed to help cure body discomforts and mind obsessions; to help break bad habits or create good ones (for example, to stop smoking or start drinking). It came as a kit of parts packaged in its own bottle. The Museum of Modern Art shop in New York used to sell them for a time. A larger version, incorporating a lamp, was also prototyped. Chrome and aluminium versions of KiiK, which I had made myself on a lathe and then assembled, were first presented at a design conference organised by Reyner Banham in Aspen, Colorado in 1968. I also designed the poster for this event, and a great paper hat, celebrating a dialogue between America and Europe. All the big guys were there, including Archigram. I even did a presentation, but since I am so shy I got the organisers to turn off the lights when I spoke. This made my slides really stand out, and the talk turned out to be really successful.

A.P. : Did you work with other industrial manufacturers? I know you were involved in the Art and Technology Program created by Maurice Tuchman at the Los Angeles County Museum of Art. In 1966, fascinated by Southern California film industry and by the futuristic technologies developed by Lockheed Aircraft, the Jet Propulsion Laboratory, or the Rand Corporation, Tuchman conceived the idea of inviting artists to use industrial laboratories and facilities as studios. The program lasted from 1967 to 1971 and eventually implicated thirty-seven corporation and seventy-eight artists including Jean Dubuffet, Roy Lichtenstein, Otto Piene, Tony Smith, Eduardo Paolozzi, Richard Serra, Claes Oldenburg, Robert Irwin, and James Turrell. It was a sort of West Coast equivalent of the Experiments in Art and Technology (E.A.T.) established in 1966 in New York by Billy Klüver, Robert Rauschenberg, and John Cage. Both programs became rather controversial and most of the artists' collaborations with industry were troubled to say the least. A lot of the projects proposed never came to fruition including yours.

F.D. : In January 1969 I was in the Los Angeles area and the A\&T program invited me for a tour of the advanced technology labs of the Ampex Corporation. My intention was to work on a vast scale using electronic transducing apparatuses that reacted to external stimuli. Ampex could not handle the scale I wanted. So I was taken to see Kaiser Steel. There scale was not a problem. A month later, I sent a proposal from Montreal. The idea was to install in and around the Museum, in parks and plazas, a sequence of solid collapsible "skins" in tension out of mobile containers. I wanted the skins to identify directions, areas, and volumes. They had to surprise. Sometime later I sent sketches and also found two steel manufactures in New York ready to collaborate. However the project was abandoned as unfeasible.

A.P. : As I said before, both E.A.T and the LACMA's program came under attack. At the time Herbert Marcuse, philosopher of the Frankfurt School, and unlikely guest of a campus in Southern California, was publishing his theses against technocracy while people were protesting the war in Vietnam and the violent technologies deployed and developed by the American military-industrial apparatus. The artists in residence were accused of producing corporate art facilitating the industries' whitewashing of war technologies. This, and the collapse of your scheme for LACMA, didn't deter you from collaborating with industry?

F.D. : No, it didn't. I had all sorts of contacts. An installation I did in 1969 for the Museum of Contemporary Art in Chicago, for example, was made from a chrome nickel wire. It was called the Laser Mou or soft laser and used the same kind of wire 
you have in a toaster that heats up and toasts your bread. Except that this was a $10 \mathrm{~m}$-longwire. The more current that passed along the wire the brighter it glowed and the lower it drooped. At the highest setting the glowing red wire appeared as a line almost as fine as a 'curved' laser beam, hence the title of the piece. Other installations had architectural, rather than industrial, references, such as the four models I first exhibited at Galerie Moos in Toronto in 1967/1968. The project was called Kubaltos and was made for Walter Netsch, who was at the time head of Skidmore, Owings and Merrill in Chicago, and mainly known for his association with brutalism and field theory, an aesthetic derived from the rotation of squares in complex forms. SOM designed a huge university plaza with four open-air auditoriums. I added towers of various sizes to the initial programme. The project scheme was never realised and my Kubaltos became a purely conceptual model organised around four structures made out of plexiglass cubes placed on top of one another and linked by four chrome tubes arranged at different heights. They could be seen as models for four fantastic skyscrapers. I remember that when the cubes were installed Walter's friend Stanley Tigerman came along to photograph them. The third project in this series was the Atomix - a sort of plexiglass sandwich that held 6,223 1$\mathrm{mm}$ stainless steel balls. These were held in a space that was really very constricted just a millimetre plus one micron. This meant that as you moved the box the balls would shift, but only very slowly and incrementally, piling up and creating interesting crystallographic patterns. These would be very similar to the patterns you would see through an electronic microscope when looking, for example, at a section of a piece of steel - atomic patterns of a material's innate properties.

A.P. : Can we talk some more about Atomix? There are many different versions of it, on different scales and formats. Sometime it becomes a drawing. I am thinking in particular of the version that appeared in your 'Desertomania' in Art in America in 1967. You call it a Urbatomic Flower. It spreads on two pages with a caption that says: "Desert landscaping from an explosion of meteoric atoms the artist creates a granular forest of continually changing shapes. He and his patron are involved in a series of progressions...' The little floating figures of patron and artist after being conditioned in a capsule, progress to a moment of expansion, reach self-expression plus psychic liberation, and conclude the cycle with a return to stability. In the introduction to 'Desertomania' you state that 'The desert is a laboratory where the artist - with the active support of his patron - works out his concept for the world of the future. The artist is concerned with the transitional and impermanent aspects of this environment, which he copes with in terms of controlled vacuums, temporary constructions and electromagnetic mirages.' The American desert in the 60s and 70s was precisely a laboratory, a testing ground for artists, scientists and the military. When I first saw your desert piece, for example, I associated it with Tinguely's Study for an End of the World, $n^{\circ} 2$, one of his extravagant acts of destruction that took place in the proximity of Las Vegas, and the Nuclear Test Site, in 1962. Like Tinguely's highly publicized performance your piece obviously refers to atomic testing and the cold war with its threat of death and annihilation. You show a fantastic city of the future 'before' an atomic explosion. But it seems to me that beyond this obvious reference you privileged the desert as environmental lab to prefigure life in space.

F.D. : Actually the Urbatomic flower was a 1967 montage of round white labels realized in silkscreen on silverized acetate. As for 'Desertomania', it is a composite of different projects and ideas that occupied me at the time. By the way I got a prize for it from the Society of Publication Designers in 1968. The opening images, soldiers holding 'blue-power' transmitting weapons, come from the settings, costumes and arms I was developing for 2020 West, a comedy-adventure series for television with a 
script written by Alan Hackney and Gerald Potterton. The hero was Kilowatt Scott, a rather silly cowboy-detective who roamed the American West in the future. He travelled in hovering air-conditioned vehicles equipped with fantastic gadgets, rode purple horses (animals in future came in different colours), and defeated enemies with outrageous weapons and the help of smart Beta Particle. A gorgeous girl based in California, Beta appeared when Kilo was in trouble and had to switch on the Physical Materialiser. We had a lot fun and I found a real stunning girl to pose for me in the futuristic costumes. Too bad we abandoned the project. Anyway, in 'Desertomania' I also transformed in spaceships the electronic machines developed for Expo 67, they did have already 'atometeoric' shapes. And you are right, the question that occupied me intensely was life in space. In 'Desertomania' the artist and patron after the esplosion travelled in 'negative' clouds, for enclosed trips, and in 'positive' clouds, for exposed one. Then I went on to explore the problem of children travelling in space.

A.P. : I assume you refer to the four pages insert published in artscanada in 1968. The short texts that are supposed to clarify the images are more cryptic than ever, but all together is really an amazing montage of projects. There are some of your fist machines like the IntroConvers-Omatic, and a flying photographic rendering of Tubula, the 'Automobile Immobile' of 1967. What dominate the composition, however, are two strange new beings called "parthenogenetics' body-machines", that seem to emerge from cosmic foam. One wonders if they are related the twin children attached to a real strange feeding apparatus composed of bottles, teats, pumps and tubes that appear on the front and back pages.

F.D. : Only an extremely small selection of the images of 'Space Baby' was used for the piece in artscanada, but I have all the documentation of the photo session. I was working with three photographers, Jeremy Taylor, John Max and Marc Lullier, and a borrowed child. This was in 1967, I think.

A.P. : Yes, or at least a photo of you and the baby floating in space connected by this crazy apparatus appears in a periodical of that year. The caption says 'super electromagnetic teats for the alimentation of babies in space'. The same article is illustrated with two more photographs: one of you in a womb-like alcove of Le Drug, and the other representing you again as proud father of the 'pregnant chair'. You are also quoted saying that the artist of the future will be a technician, like yourself. At this particular stage you do seem obsessed with reproduction, oscillating between fathering and nurturing cybernetic organisms adapted to space and the idea of being yourself contained in a technological womb like the environmental bubble. A couple of years later you became a father for real. I think it is quite significant that you include in the list of your works the photographs of your wife Judith vastly pregnant. You used a lot of them to introduce your piece in the 1970 issue of Design Quarterly about the 'environment'. Maybe we can borrow again an interpretation from Sloterdijk. In a 2009 interview with himself, Sloterdijk provocatively declares that women's bodies are apartments. Or should I ask you if the environmental bubble from your point of view is a primitive hut in the sense proposed by Sloterdijk of technological uterus?

F.D. : It's a possibility.

A.P. : You mentioned earlier that you are not much of a writer and yet the names you give your projects are always interesting. Titling projects seems to be one way you feel confident in expressing your work.

F.D. : I think I have always been good at coming up with names for my projects, whether these have been for cars like Super Leo, for machines like the Cuisinomatic, for buildings like Le Drug or the Villa Ironique, or my Atomix, KiiK and Kubaltos models. Perhaps my favourite one, though, was The Art Breaker - a gold- and silver-plated device produced in an edition of 500 in 1974. As with KiiK the MoMA shop sold it and 
also like KiiK it was an object that you had to hold, physically, in your hands, in order to understand or realise it. You would use it to express a message - that you love somebody or the reverse, that you don't love them anymore. It's basically a message bearer. This device, I think, was really close to my own sensibilities, because, ultimately, I think it really helps to have a good cry now and again.

A.P. : To me, François, you seem to function mainly in an ironic, if not to say sarcastic, mode. What about the Villa Ironique, a version of which is hanging over the sofa in your living room? I have been looking at it and puzzling over its meaning for awhile now. Could you tell me something about it?

F.D. : This was a project I developed later, around 1983, and a number of different versions and editions exist. In one you see a scaffolding system, which I have been working with since the 60s. It moves like an accordion and is supported by two pylons that can be seen as reversed Ionic columns. The capitals are transformed into wheels. The caption that goes with this scheme reads: 'Project for a home-making machine, ultimate hatcher with nonchalant triangulations to handle the otherwise impossible mission to excrete an appropriate minimum vital, silly silo conceived to procreate instantly, like no other device on earth, out of any bits and pieces falling straight from outer space'. On the photomontage that you see over the sofa, I am seen representing a previous, more primitive, version of the villa. I call it the Manure Palace. It is literally a mound of manure. Sometimes plants are seen growing out of it, and in this one I added real straw. I am shown pushing open a door to get out of the palace and waving at the camera. There is a caption for this image too, in French and English: Habitas de fumier. ZAP Zone d'Architecture Postmerdique comme Premier Substitut Social en Tas (psst). Manure palace. Premier tas issu de la Villa Ironique pour une Cabane au Canada vraiment confortable. MX Shelter, pile of Manure Xenophobia as a postmodern Alternative Housing for the Average Habitant (ahah). First dropping by the Villa Ironique, an improved 'Cabane ô Canada'.

A.P. : This is really quite a lot of text from a man who claims to be not much of a writer. Were you using the project to poke fun at the end of modernism and postmodernism, mourning over the $60 s^{\prime}$ utopias and the fantasies of the future, and lamenting the situation in Canada, especially in Montreal, in the early 80s?

F.D. : I don't know. Maybe. You decide. 
Figure 1 : Total environment

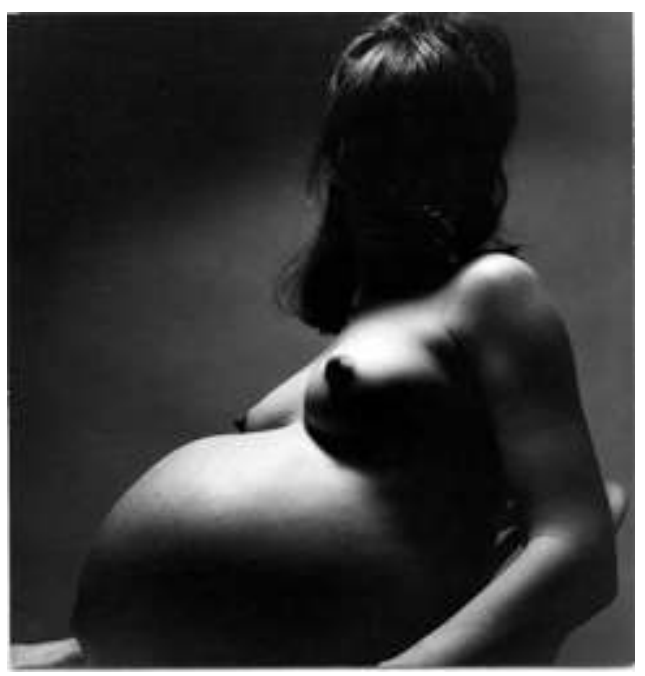

Judith 69 (c) 1969 François Dallegret

Figure2 : Total environment

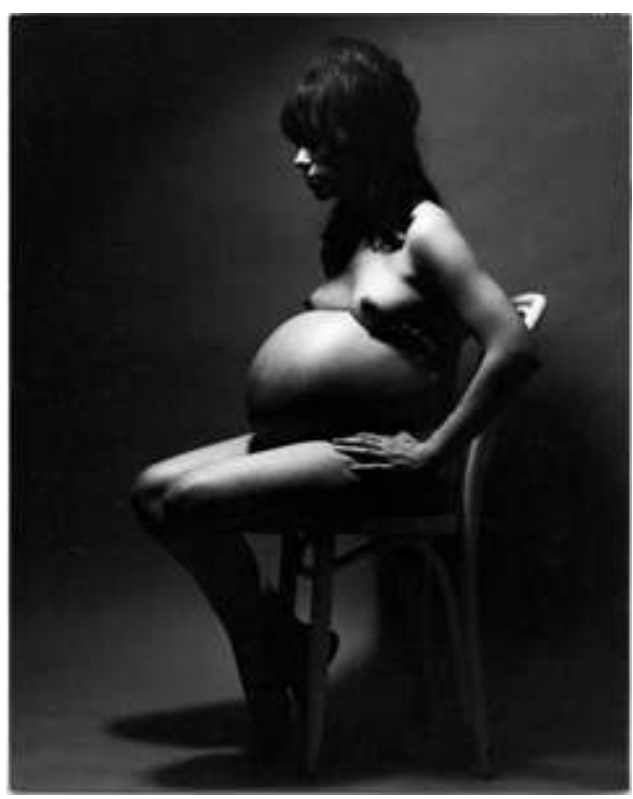

JUDITH 69 ( 1969 FRANÇOIS DALLEgRET

\section{BIBLIOGRAPHY}

Architectural Forum, ‘Gallery: The Visions of Mr. Dallegret', May 1964.

Aujourd'hui Art et Architecture, May/June 1966. 
Banham Reyner, Dallegret François, “A Home Is Not a House”, Art in America, n 2, April 1965. Banham Reyner (ed.), The Aspen Papers: Twenty Years of Design Theory from the International Design Conference in Aspen, New-York/Washington, Praeger Publishers, 1974.

Banham Reyner, Megastructure: Urban Futures of the Recent Past, New York, Harper \& Row, 1976. Blake Peter, "François Dallegret: A Catalogue", Arts Canada, February/March 1972, vol. 29, nº 1, pp. 66-69.

Blake Peter, Form Follows Fiasco: Why Modern Architecture Hasn't Worked, Boston, Little Brown, 1974. Blake Peter, No Place Like Utopia: Modern Architecture and the Company We Kept, New York, Knopf, 1993.

Boulain J. A., « Les plus jeunes matériaux », illustrated by François Dallegret, Pétrole Progrès, $\mathrm{n}^{\circ}$ 55, 1962.

Burnham Jack, Beyond Modern Sculpture: The Effects of Science and Technology on the Sculpture of This Century, London, Allen Lane The Penguin Press, 1968.

Burns Jim, Arthropods: New Design Futures, New York, Praeger, 1972.

Design Quarterly (special double issue on conceptual architecture), $\mathrm{n}^{\text {os }} 78 / 79,1970$.

Clert Iris, iris.time: l'artventure, Paris, Éditions Denoël, 1978.

Couture Francine (ed), Les arts et les années 60, Montreal, Éditions Triptyque, 1991.

Dahinden Justus, Structures urbaines de demain : Analyses, Thèses, Projets [1 ${ }^{\text {st }}$ German edition, 1971], Paris, Éditions du Chêne, 1972.

Dallegret François, Sheppard Gordon and Ungerer Tomi, The Wild Oats, Inc, promotional brochure, 1966.

Dallegret François, "Plook” and “Art on TV”, Art in America, December/January, 1965/1966.

Dallegret François, “François Dallegret's Art Fiction”, Art in America, March/April 1966, pp. 44-48.

Dallegret François, “The Future: Desertomania”, Art in America, July/August 1967, pp. 32-39.

Dallegret François, “Dallegret: Idee per Montreal”, Domus, January 1967.

Dallegret François, "Psychedelic Marketing - Palais Metro”, Art in America, July/ August, 1968.

Dallegret François, “The Arrogance of Art a visual statement on art/architecture/time/space in the form of a fantastic voyage of a human child in outer space", Arts Canada, $\mathrm{n}^{\circ} 120-121$, August 1968, pp. 9-12.

Dallegret François, “Sound and Image: La Machine”, Arts Canada, June 1968.

Dallegret François, “Fun House”, Esquire, May 1969.

Déclics: Art et Société, Le Québec des années 1960 et 1970, exhibition catalogue, Québec, Musée de la civilisation/Musée d'art contemporain de Montréal, 1999.

Hight Christopher, "Putting Out the Fire with Gasoline: Parables of Entropy and Homeostasis from the Second Machine Age to the Information Age", Michael Hensel, Christopher Hight, Achim Menges (eds), Space Reader: Heterogeneous Space in Architecture, Chichester, John Wiley \& Sons, 2009, pp. 159-172.

Hackney Alan, Potterton Gerald, 2020 West: A Comedy-Adventure Series for Television, typescript, January 1967. 
Klein Yves, “Chelsea Hotel Manifesto" [1961], Rotraut Klein-Moquay, Robert Pincus-Witten, Yves Klein USA, Paris, Dilecta, 2009.

Kulper Amy, "Ecology without the Oikos: Banham, Dallegret and the Morphological Context of Environmental architecture", field: a free journal for architecture, vol. 4, n 1, 2011, pp. 67-84, www.field-journal.org

Lambert Jean-Clarence, Restany Pierre, Bernard Quentin: Des graffiti aux monuments, Paris, Cercle d'Art, 1991.

Lee Pamela M., Chronophobia: On Time in The Art of the 1960s, Cambridge (Mass.), The MIT Press, 2004.

Lortie André (ed), The 60s: Montréal Think Big, Montreal, Canadian Centre for Architecture, 2004. Loewy Raymond, Industrial Design, Woodstock/New York, The Overlook Press, 1979.

Loewy Raymond, Never Leave Well Enough Alone [1951], Baltimore/London, The John Hopkins University Press, 2002.

Noever Peter, Perrin François (eds), Yves Klein: Air Architecture, Ostfildern-Ruit, Hatje Cantz Verlag, 2004.

Pontus Hultén Karl. G., Jean Tinguely “Méta” [first German edition 1972], Boston, New York Graphic Society, 1975.

Pontus Hultén Karl. G., Tinguely: Une Magie plus forte que la mort, Paris, Le Chemin Vert, 1987.

Rich Sarah K, “François Dallegret's Astrological Automobiles: Occult Commodities for France in 1960", Oxford Art Journal, 2008, pp. 1-23.

Robillard Yves (ed), Québec Underground, 1962-1972, 3 vols, Montréal, Éditions Médiart, 1973.

Ruddy John, « Un art gai pour une époque triste [Francois Dallegret] », Le Magazine Maclean, May 1967, pp. 70-71.

Sloterdijk Peter, Écumes, Sphère III [1 $1^{\text {st }}$ German edition 2003], Paris, Marel Sell Éditeurs, 2005.

Sloterdijk Peter, Spheres Theory: Talking to Myself about the Poetics of Space, Harvard University Graduate School of Design, lecture February 17, 2009, www.gsd.harvard.edu/events/pdf/PeterSloterdijk.

Sowa Axel, « L'Infra-Ordinaire de François Dallegret », L'Architecture d'Aujourd'hui, May/June, 2001, pp. 106-111.

Paul Thek/Processions, exhibition catalogue, Philadelphia, Institute of Contemporary Art, 1977.

Tuchman Maurice, Art \& Technology: A Report of the Art \& Technology Program of the Los Angeles County Museum of Art 1967-1971, Los Angeles County Museum of Art (Distributed by Viking Press, New York), 1971.

Vernes Michel (in collaboration with Anne Claude Renoue), "Dallegret”, Architecture Intérieure/ Créé, $\mathrm{n}^{\circ} 200,1984, \mathrm{pp} .102-117$. 